\title{
Multiple stresses on the oxidative metabolism of sugarcane varieties
}

\author{
Marciana Bizerra de Morais $^{1} \odot$ Terezinha Rangel Camara $^{2} \odot$ Cláudia Ulisses $^{3} \odot$ \\ José Luiz Sandes Carvalho Filho $^{4}$ Lilia Willadino ${ }^{3 *} \odot$
}

'Programa de Pós-graduação em Ciência Naturais (PPGCN), Universidade do Estado do Rio Grande do Norte (UERN), Mossoró, RN, Brasil. ${ }^{2}$ Departamento de Química, Universidade Federal Rural de Pernambuco (UFRPE), Recife, PE, Brasil.

${ }^{3}$ Departamento de Biologia, Universidade Federal Rural de Pernambuco (UFRPE), 52171-900, Recife, PE, Brasil. E-mail: willadino.lilia@gmail.com. "Corresponding author.

${ }^{4}$ Departamento de Agronomia, Universidade Federal Rural de Pernambuco (UFRPE), Recife, PE, Brasil.

\begin{abstract}
The exposure of plants to multiple stress conditions can cause over production of reactive oxygen species promoting an imbalance in the redox system. The aim of this study was to examine the antioxidant response from varieties of sugarcane under adverse conditions, to understand the defense mechanisms of tolerant and sensitive genotypes. Micropropagated sugarcane of six genotypes, RB966928, RB98710, $R B 855453, R B 99395, R B 867515$, and RB855156, were subjected to isolated action of high-temperature stress and a combination of water and saline stress, and effects were evaluated. Activities of enzymes such as superoxide dismutase (SOD), catalase (CAT), and ascorbate peroxidase (APX), as well as stress indicators such as lipid peroxidation (MDA content) and hydrogen peroxide $\left(\mathrm{H}_{2} \mathrm{O}_{2}\right)$ content were evaluated. The RB867515 variety showed synchrony between the enzymatic activity and ROS regulation and detoxification, in the plant cell under environmental stress situations, thereby ensuring the maintenance of the relative water content without increment of lipid peroxidation; and consequently, the maintenance of physiological processes and plant growth. These results indicated that lipid peroxidation associated with relative water content can be good biochemical markers of sensitivity to multiple stresses in sugarcane.
\end{abstract}

Key words: antioxidant enzyme, abiotic stress, Saccharum, ROS.

Estresse múltiplo no metabolismo oxidativo de variedades de cana-de-açúcar

RESUMO: A exposição de plantas a condições de estresse múltiplo pode causar uma superprodução de espécies reativas de oxigênio promovendo desequilibrio no sistema redox. O objetivo deste trabalho foi estudar a resposta antioxidante de variedades de cana-de-açúcar sob condições adversas visando a compreensão de mecanismos de defesa de genótipos tolerantes e sensiveis. Mudas micropropagadas de cana-de-açúcar de seis genótipos, RB966928, RB98710, RB855453, RB99395, RB867515 e RB855156 foram submetidas à avaliação da ação isolada do estresse por alta temperatura e da sua combinação com o estresse hidrico e salino. Avaliou-se a atividade das enzimas superóxido dismutase (SOD), catalase (CAT) e ascorbato peroxidase (APX), bem como a peroxidação lipídica (teor de MDA) e teor de peróxido de hidrogênio $\left(\mathrm{H}_{2} \mathrm{O}_{2}\right)$, indicadores de estresse. A variedade RB867515 destacou-se por apresentar sincronia entre a atividade enzimática na regulação e desintoxicação das ROS, produzidas na célula vegetal durante situações de estresse ambiental, garantindo a manutenção do teor relativo de água sem incremento da peroxidação lipídica e, consequentemente, a manutenção dos processos fisiológicos e o crescimento da planta. Os resultados indicam que a peroxidação lipídica associada ao baixo teor relativo de água podem ser bons marcadores bioquímicos de sensibilidade da cana-de-açúcar à estresses múltiplos.

Palavras-chave: enzimas antioxidantes, estresses abióticos, Saccharum, ROS.

\section{INTRODUCTION}

Plants are exposed to a range of abiotic conditions in natural habitats that can change their metabolism. Such conditions may include high light, drought, high temperature, and salinity. Studies on oxidative stress, associated with abiotic stresses in plants have advanced considerably (AZEVEDO et al., 2011). However, most of the research is focused on individual stresses, even though it is known that plants in the field are exposed to adverse conditions that occur simultaneously (RIZHSKY et al., 2004).

Studies in Arabidopsis exposed to a combination of heat and drought stresses revealed a new defense response pattern, different from those observed in studies examining the effects of individual stress factors (RIZHSKY et al., 2004, KOUSSEVITZKY et al., 2008). Therefore, a 
better understanding of the mechanisms in plants for acclimatization to environmental fluctuations is required in economically important crops such as sugarcane (Saccharum spp.), to facilitate the selection or development of varieties that can tolerate environmental extremes, so that they can reach a new state of homeostasis when exposed to a given stress (MILLER et al., 2010).

The economic relevance of sugarcane production has been mainly associated with the production of sugar and ethanol. Brazil is currently considered the leading producer of sugar in the world. Sugarcane is also considered the main feedstock for the production of second-generation ethanol (AZEVEDO et al., 2011; BOARETTO \& MAZZAFERA, 2013). Areas of cultivation have been expanding to the semi-arid region of the country, with soil and climatic conditions that can lead to soil salinization (WILLADINO et al., 2011), water deficiency, and high temperatures. This expansion will expose the plants to new combinations of different stresses.

Exposure to single or multiple environmental stresses, can increase reactive oxygen species (ROS) production and lead to oxidative stress. Duration and intensity of the stress, phenological stage, and genotype are factors that may influence the response of the plant (GHELFI et al., 2011). Plants have; therefore, developed an antioxidant defense mechanism by the synthesis of metabolites and activation of an enzymatic system (AGARWAL \& PANDEY, 2004). Enzymes catalyze the decomposition of oxidative molecules that can severely affect the integrity and functionality of cells, often causing irreparable damage (MOLLER et al., 2007).

This study presents physiological responses and pathways of antioxidant defense metabolism in six varieties of sugarcane exposed at early growth stages to high temperatures, with or without water and salt stresses. Results provided important tools for the guidance of plant breeding programs, with the aim to produce progeny with higher tolerance to environmental stresses.

\section{MATERIALS AND METHODS}

Micropropagated plantlets of six "RB" (Republic of Brazil), a Portuguese sugarcane variety, were used in this study: RB966928, RB98710, RB855453, RB99395, RB867515, and RB855156. Plants were acclimated in a greenhouse, growing in cone-shaped plastic tubes, with a capacity of $115 \mathrm{~cm}^{3}$, containing washed sand. After 15 days of acclimatization (relative humidity of
$65 \% \pm 5.5 \%$ and temperature of $29.61 \pm 0.97^{\circ} \mathrm{C}$ ), the plants were transferred to a climate chamber (modelSL-205/1370; SOLAB), with a photoperiod of $12 \mathrm{~h}$, for five days. Plants were watered with half-strength Hoagland solution (HOAGLAND \& ARNON, 1950) before exposure to stresses.

Three different stressing agents were used in the experiment: high temperature, salinity, and drought, individually or in combination. Experiments were conducted in growth chamber under controlled environmental conditions of $36 \pm 1^{\circ} \mathrm{C}$ during the day and $26 \pm 1{ }^{\circ} \mathrm{C}$ during the night, relative humidity of $40 \% \pm 8 \%$, and radiation of $300 \mu \mathrm{mol} \mathrm{m} \mathrm{m}^{-2} \mathrm{~s}^{-1}$.

After acclimatization in the chamber, four treatments were established. Plants in groups $\mathrm{T} 1$ and T2 were watered daily with nutrient solution and plants in groups $\mathrm{T} 3$ and $\mathrm{T} 4$ received nutrient solution, supplemented with $\mathrm{NaCl}$ to achieve the concentration of $50 \mathrm{mM}$ (electrical conductivity of $5.8 \mathrm{dS} \mathrm{m}^{-1)}$. On the ninth day of culture, watering was suspended in plants under T2 and T4 treatments. Therefore, the growing conditions were as follows: $\mathrm{T} 1=$ no $\mathrm{NaCl}$ treatment and continuous watering (temperature stress); $\mathrm{T} 2=$ no $\mathrm{NaCl}$ treatment and suspension of watering (water + temperature stress), T3 = continuous watering and salt solution (saline + temperature stress); and T4 = suspension of watering after saline stress (water + saline + temperature stress). The experimental period was 12 days.

Design was completely randomized in $6 \times 4$ factorial scheme (six varieties and four growing conditions), with four replicates $(n=3)$, each consisting of one plant per tube. Data were submitted to variance analysis and the averages were compared by Tukey test at 5\% probability using ASSISTAT 7.7 (SILVA \& AZEVEDO, 2016). Relationship between the variables was determined by the correlation matrix, using the software ASSISTAT 7.7. Results demonstrated the existence of significant and positive correlation between some variables. After collection, the plants were immediately frozen in liquid nitrogen and kept at $-20{ }^{\circ} \mathrm{C}$ until further analysis.

The relative water content (RWC) was determined using the method of WEATHERLEY (1950), hydrogen peroxide $\left(\mathrm{H}_{2} \mathrm{O}_{2}\right)$ was quantified according to the protocol of ALEXIEVA et al. (2001), and lipid peroxidation was determined as previously described (HEATH \& PACKER, 1968). To determine enzymatic activity, an enzymatic extract was prepared following the methodology of AZEVEDO et al. (1998). The catalase (CAT) activity was determined by the method described by HAVIR \& MCHALE (1987) with modification according to AZEVEDO et 
al. (1998). The ascorbate peroxidase (APX) activity was determined as described by NAKANO \& ASADA (1981). Determination of superoxide dismutase SOD followed the standard protocol of GIANNOPOLITIS \& RIES (1977). Total protein concentration was determined using the method of BRADFORD (1976).

\section{RESULTS AND DISCUSSION}

The varieties RB98710 and RB855453 showed a decrease in RWC when plants were exposed to high temperature stress associated with water stress (T2). In contrast, following exposure to both temperature and saline stresses (T3), only the variety RB855453 showed reduction in RWC, compared to the control. The intensity and significance of this reduction in the RWC were higher when plants were exposed to all three stresses (temperature + water + saline $=\mathrm{T} 4$ ). Reductions in RWC of about $35 \%$ were observed in this treatment, with the exception of varieties RB867515 and RB855156, which showed only reductions of $17 \%$ and $22 \%$, respectively (Figure $1 \mathrm{~A}$ ).

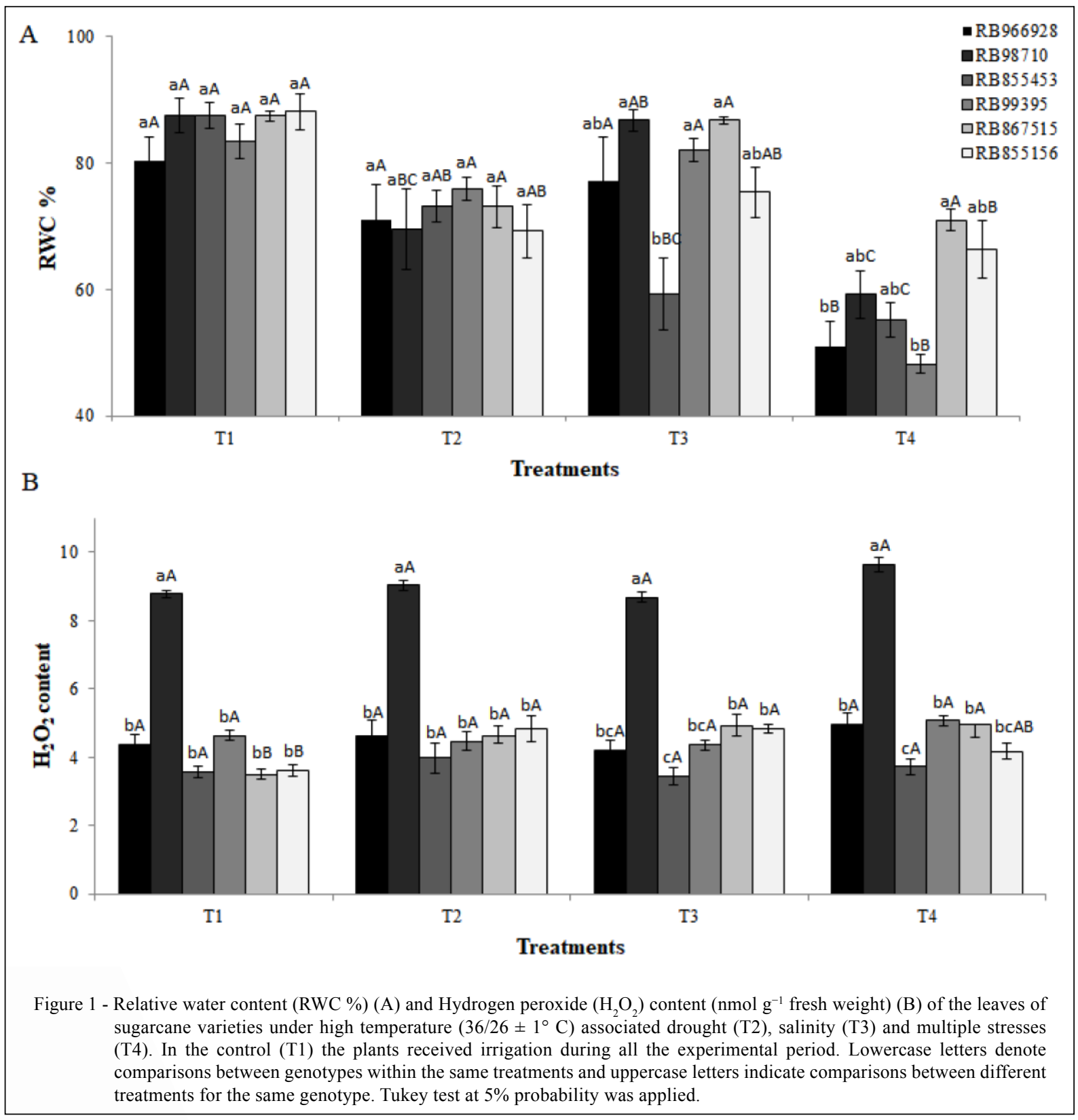

Ciência Rural, v.48, n.4, 2018. 
WAHID \& CLOSE (2007) showed that S. officinarum plants (clone NCO-310) expose $\mathrm{d}$ to high temperatures $\left(40 / 35 \pm 1{ }^{\circ} \mathrm{C}\right)$ also had a decrease in RWC, reducing the water content in the cell. However, the RWC values were similar to the ones of the control plants after $72 \mathrm{~h}$ of treatment, suggesting that plants were able to adjust osmotically during this short period.

The varieties RB966928, RB98710, RB99395, RB867515 and RB855156, exposed to a combined stress of high temperature and salinity (T3), was similar to the one observed for T1. Such behavior can promote tolerance to saline stress associated with high temperatures, since plants preserved their water content similar to those of the plants that received no salt (Figure 1A).

Hydrogen peroxide $\left(\mathrm{H}_{2} \mathrm{O}_{2}\right)$, as a strong oxidant, causes damage and affects metabolic functions at the site in the cell where it accumulates (FOYER et al., 1997). However, other ROS that accumulate also cause direct or indirect effects in the cells, including lipid peroxidation (SMIRNOFF, 1993), which can be detected by an increase in malondialdehyde (MDA) levels. Therefore, TRIANTAPHYLIDÈS et al. (2008) considered that lipid peroxidation is almost exclusively mediated by ${ }^{1} \mathrm{O}_{2}$. For the sugarcane varieties analyzed in this study, there was no correlation between MDA content and $\mathrm{H}_{2} \mathrm{O}_{2}$ concentration in any of the varieties. Therefore, besides not causing damages, the increase in the $\mathrm{H}_{2} \mathrm{O}_{2}$ content observed in $\mathrm{RB} 867515$ and RB855156 suggests generation of this ROS from other metabolic processes, such as signaling (Figure 1B).

A significant increase in MDA content, product of polyunsaturated fatty acids peroxidation from biomembranes was detected and varied with the sugarcane variety and type of stress. TAYEBIMEIGOONI et al. (2012) studied the effects of salinity in cabbage and also observed that MDA content differed between cultivars and saline treatment. The RB99395 seems very sensitive to increases in temperature, as high MDA levels were observed in plants exclusively exposed to this stress (T1). These high MDA levels remained constant after association of the temperature stress with the saline and water stresses, individually or in combination. In the varieties RB98710 and RB966928, the increase in MDA content was accompanied by a reduction in RWC (Figures 2A and 1A) and negative correlations were observed $\left(r=-0.5705^{*}\right.$ and $r=-0.5425^{*}, \mathrm{P}<0.05$ respectively). Increases in MDA content have been associated with oxidative stress and, among other factors, may indicate failure of the antioxidant system (TAYEBIMEIGOONI, 2012).
According to SCANDALIOS (2005), damage in the plasma membrane is often associated with leakage of electrolytes and cell death; and therefore, peroxidation has been used as a marker in the selection of cultivars (SHAO et al., 2005; LATA et al., 2011). The variety RB867515 showed no significant difference of MDA in leaf tissues exposed to combined stresses (Figure 2A). The variety RB98710 maintained a low MDA content for the temperature stress (T1) and the dual combination of temperature stress with water (T2). In the triple stress combination, an increase in MDA content was observed in RB98710. Low MDA levels are representative of tolerance in sugarcane genotypes exposed to water deficiency (CIA et al., 2012).

The enzymatic antioxidant system, represented by the activities of SOD, APX, and CAT, showed significant differences in responses among on genotypes and treatments (Figures 2B, 3A and 3B). In general, were observed significant increases in SOD activity (mainly in RB855453 variety in T2), a $\mathrm{H}_{2} \mathrm{O}_{2}$ generator, which suggested the presence of superoxide radical (Figure 2B). In parallel, occurred the maintenance or increase of CAT and APX activities. It is important to note that SOD activity is associated with CAT and/or APX activities. The SOD dismutation product of $\mathrm{O}_{2}{ }^{-}$is $\mathrm{H}_{2} \mathrm{O}_{2}$, which is detoxified by APX and CAT, since its accumulation can be as damaging as accumulation of $\mathrm{O}_{2}^{-}$. In this study, CAT activity was significantly positively correlated with SOD activity in most varieties: RB966928 (0.5621*), RB855453 $\left(0.5367^{*}\right), \quad \mathrm{RB} 99395 \quad\left(0.5036^{*}\right)$, and RB867515 $\left(0.8452^{* *}\right), \mathrm{P}<0.05$.

The APX and CAT enzymes, that catalyze the degradation of $\mathrm{H}_{2} \mathrm{O}_{2}$, have different affinities for this ROS. The APX has high affinity $(\mu \mathrm{M})$ and CAT has a low affinity (mM) (MITTLER, 2002). Moreover, APX can degrade $\mathrm{H}_{2} \mathrm{O}_{2}$ that is inaccessible to CAT, such as in chloroplasts (FOYER \& NOCTOR, 2011). Results of this study demonstrated the importance of a concomitant increase in the activity of these two enzymes for protection against oxidative damage. In the variety RB867515, CAT and APX showed a highly significant positive correlation $\left(0.8316^{* *}, \mathrm{P}<0.05\right)$. Similar results have been associated with tolerance to water deficiency in wheat (SAIRAM et al., 1998) and to salinity in sugarcane (WILLADINO et al., 2011). Increase or maintenance of APX and CAT activities indicates the importance of these enzymes in $\mathrm{H}_{2} \mathrm{O}_{2}$ detoxification and protection against oxidative damage (CIA et al., 2012).

Response patterns for the varieties RB966928 and RB855453 clearly show the 


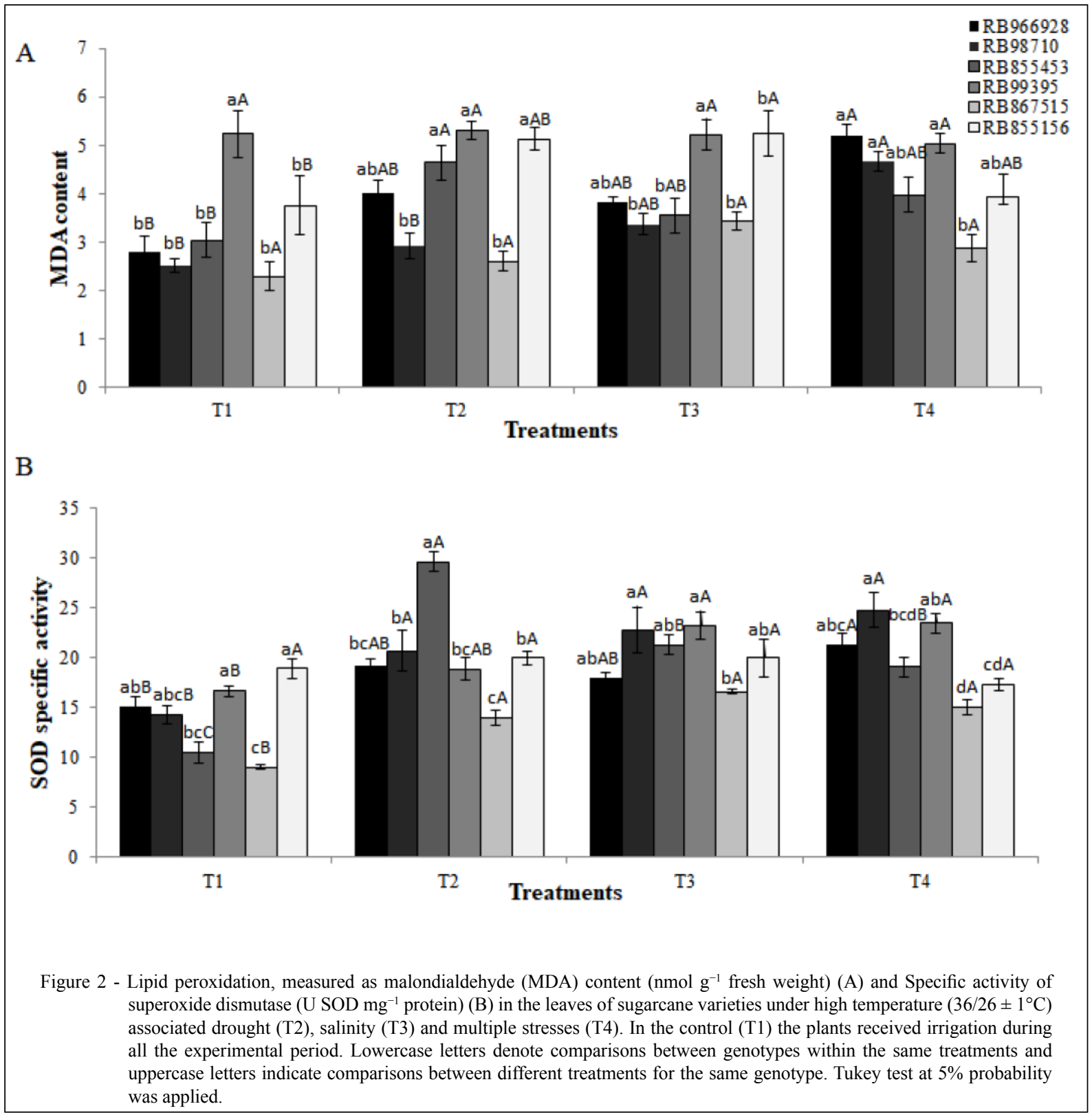

differences of each genotype exposed to the same stress conditions. Both varieties showed the greatest decreases in RWC levels. However, the variety RB966928 showed a low increase in enzymatic antioxidant system when compared to the variety RB855453.

In this study, plants were exposed to water stress, saline stress or water + saline stress, always at high temperature. The combination of stresses resulted in more severe and harmful effects to plants development, which is supported by a
RWC below $58 \%$ in most varieties. Conversely, the varieties RB855156 and RB867515 maintained an RWC of $66 \%$ and approximately $70 \%$, respectively. The variety RB867515 showed not only the higher RWC levels, but also the lowest MDA content, and was the only variety showing a positive correlation between all enzymes of the antioxidant defense system: SOD, CAT, and APX. This synchronized enzymatic activity of the variety RB867515 was effective in the regulation and detoxification of ROS produced in the plant cell, indicating the 


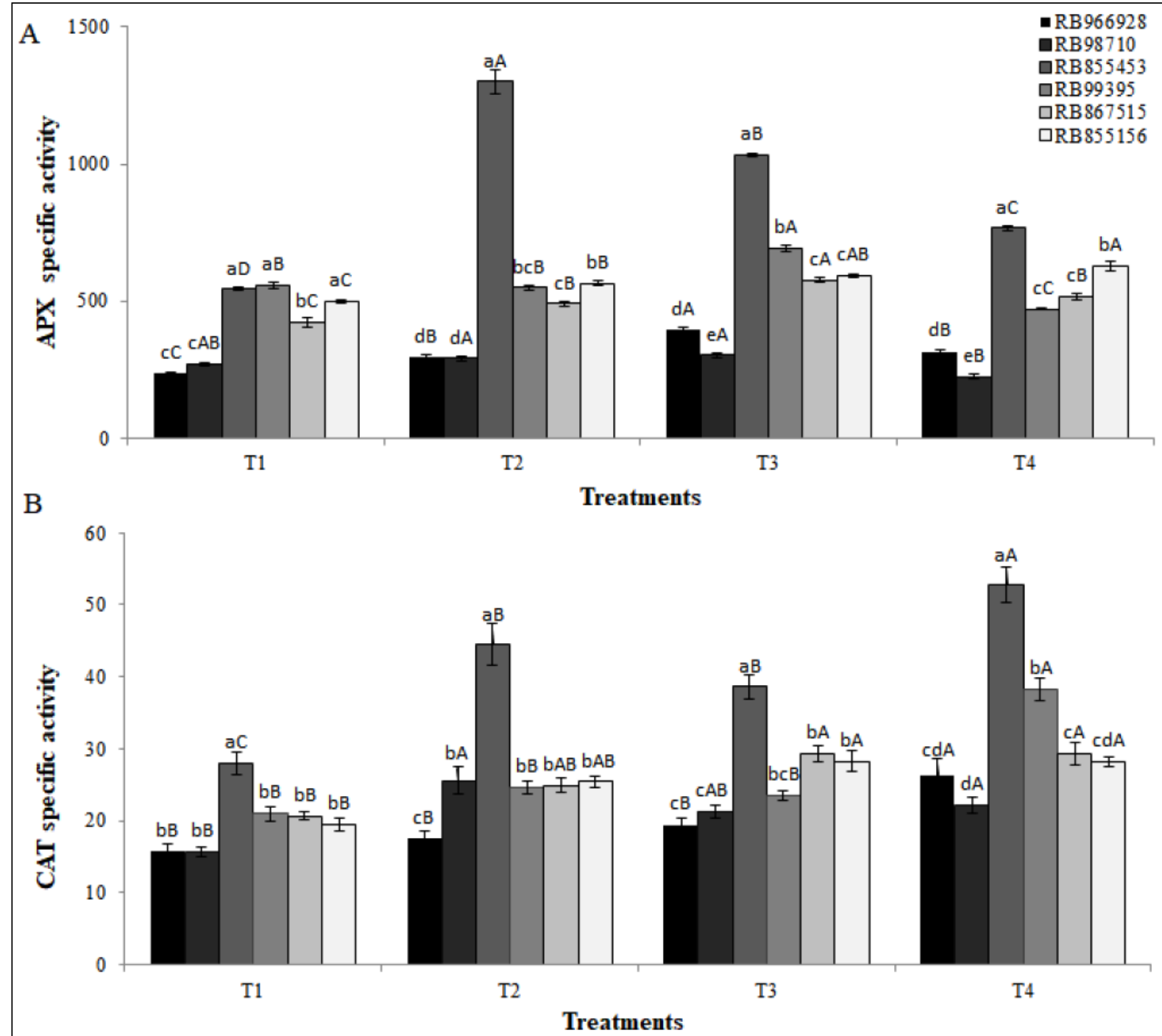

Figure 3 - Specific activity of ascorbate peroxidase (APX) ( $\mu \mathrm{mol} \mathrm{min}^{-1} \mathrm{mg}^{-1}$ protein) (A) and specific activity of catalase (CAT) $\left(\mu \mathrm{mol} \mathrm{min}^{-1} \mathrm{mg}^{-1}\right.$ protein) (B) in the leaves of sugarcane varieties under high temperature $\left(36 / 26 \pm 1^{\circ} \mathrm{C}\right)$ associated drought (T2), salinity (T3) and multiple stresses (T4). In the control (T1) the plants received irrigation during all the experimental period. Lowercase letters denote comparisons between genotypes within the same treatments and uppercase letters indicate comparisons between different treatments for the same genotype. Tukey test at $5 \%$ probability was applied.

higher tolerance of this variety to the different types of stresses, alone or in combination, compared to the other varieties tested.

Different responses of the varieties suggested differential mechanisms in the control of ROS and oxidative stress. However, high MDA levels, associated with low RWC during stress conditions, can be effective indicators of sensitivity to multiple stresses in sugarcane varieties. Synchronized activity of SOD, CAT, and APX suggests metabolic protection and may indicate tolerance to multiple stresses.

\section{ACKNOWLEDGMENTS}

We thank the Fundação de Amparo à Ciência e Tecnologia de Pernambuco (FACEPE) for funding the research (PBPG-0924-5.01/10).

\section{DECLARATION OF CONFLICTING INTERESTS}

The authors declared no potential conflicts of interest with respect to the research, authorship, and/or publication of this article. 


\section{REFERENCES}

AGARWAL, S.; PANDEY, V. Antioxidant enzyme responses to $\mathrm{NaCl}$ stress in Cassia angustifoli. Biologia Plantarum, v.48, p.555-560, 2004. Available from: < http://link.springer.com/article/ 10.1023\%2FB\%3ABIOP.0000047152.07878.e7>. Accessed: Dec. 01, 2012. doi: 10.1023/B:BIOP.0000047152.07878.e7.

ALEXIEVA, V. et al. The effect of drought and ultraviolet radiation on growth and stress markers in pea and wheat. Plant, Cell and Environment, v.24, p.1337-1344, 2001. Available from: <http:// onlinelibrary.wiley.com/doi/10.1046/j.1365-3040.2001.00778.x/ abstract $>$. Accessed: Jul. 15, 2012. doi: 10.1046/j.13653040.2001.00778.x.

AZEVEDO, R.A. et al. Response of antioxidant enzymes to transfer from elevated carbon dioxide to air and ozone fumigation, in leaves and roots of wild-type and catalase-deficient mutant of barley. Physiologia Plantarum, v.104, p.280-292, 1998. Available from: $<$ http://onlinelibrary.wiley.com/doi/10.1034/j.13993054.1998.1040217.x/abstract $>$. Accessed: Jun. 10, 2011. doi: 10.1034/j.1399-3054.1998.1040217.x.

AZEVEDO, R.A. et al. Sugarcane under pressure: an overview of biochemical and physiological studies of abiotic stress. Tropical Plant Biology, v.4, p.42-51, 2011. Available from: <http://link. springer.com/article/10.1007\%2Fs12042-011-9067-4>. Accessed: Oct. 15, 2012. doi: 0.1007/s12042-011-9067-4.

BOARETTO, L.F.; MAZZAFERA, P. Annals of Applied Biology, v.163, p.12-22, 2013. The proteomes of feedstocks used for the production of second-generation ethanol: a lacuna in the biofuel era. Available from: <http://onlinelibrary.wiley.com/doi/10.1111/ aab.12031/abstract>. Accessed: Jun. 15, 2014. doi: 10.1016/j. plaphy.2013.11.016.

BRADFORD, M.M. A rapid and sensitive for the quantitation of microgram quantities of protein utilizing the principle of proteindye binding. Analytical Biochemistry, v.72, p.248-254, 1976.

WEATHERLEY, P.E. Studies in the water relations of the cotton plant. I- The field measurements of water deficits in leaves. New Phytologist, v.49, p.81-97. 1950. Available from: <http:// onlinelibrary.wiley.com/doi/10.1111/j.1469-8137.1950.tb05146.x/ abstract>. Accessed: Dec. 17, 2012

CIA, M.C. et al. Antioxidant responses to water deficit by drought-tolerant and-sensitive sugarcane varieties. Annals of Applied Biology, v.161, p.313-324, 2012. Available from: <http:// onlinelibrary.wiley.com/doi/10.1111/j.1744-7348.2012.00575.x/ abstract>. Accessed: Nov. 28, 2012. doi: 10.1111/j.17447348.2012.00575.x.

FOYER, C.H. et al. Hydrogen peroxide and glutathione-associated mechanisms of acclimatory stress tolerance and signaling. Physiologia Plantarum, v.100, p.241-254, 1997. Available from: $<$ http://onlinelibrary.wiley.com/doi/10.1111/j.1399-3054.1997. tb04780.x/abstract $>$. Accessed: Jan. 11, 2011. doi: 10.1111/j.13993054.1997.tb04780.x.

FOYER, C.H.; NOCTOR, G. Ascorbate and glutathione: the heart of the redox hub. Plant Physiology, v.155, p.2-18, 2011. Available from: <http://www.ncbi.nlm.nih.gov/pmc/articles/ PMC3075780/>. Accessed: Jun. 12, 2012. doi: 10.1104/ pp.110.167569.
GHELFI, A. et al. Cloning, expression, molecular modeling and docking analysis of glutathione transferase from Saccharum officinarum. Annals of Applied Biology, v.159, p.267-280, 2011. Available from: <http://onlinelibrary.wiley.com/doi/10.1111/ j.1744-7348.2011.00491.x/abstract>. Accessed: Oct. 23, 2012. doi: 10.1111/j.1744-7348.2011.00491.x.

GIANNOPOLITIS, C.N.; Ries, S.K. Superoxide dismutases: I. Occurrence in higher plants. Plant Physiology, v.59, p.309314, 1977. Available from: <http://www.plantphysiol.org/ content $/ 59 / 2 / 309>$. Accessed: Jan. 20, 2013. doi: 10.1104/ pp.59.2.309.

HAVIR, E.A.; MCHALE, N.A. Biochemical and developmental characterization of multiple forms of catalase in tobacco leaves. Plant Physiology, v.84, p.450-455, 1987.

HEATH, R.L.; PACKER, L. Photoperoxidation in isolated chloroplast. I. Kinetics and stoichiometry of fatty acid peroxidation. Archives of Biochemistry and Biophysics, v.125, p.189-198, 1968. Available from: <http://www.sciencedirect.com/science/ article/pii/0003986168906541>. Accessed: Jan. 24, 2012. doi: 10.1016/0003-9861(68)90654-1.

HOAGLAND, D.R.; Arnon, D.I. The water culture method for growing plants without soil. California Agriculture Experimental Station Circular, $1950.347 \mathrm{p}$.

KOUSSEVITZKY S, et al. Ascorbate peroxidase 1 plays a key role in the response of Arabidopsis thaliana to stress combination. The Journal of Biological Chemistry, v.283, p.34197-34203, 2008.

LATA, C. et al. Differential antioxidative responses to dehydration induced oxidative stress in core set of foxtail millet cultivars. Protoplasma, v.248, p.817-828, 2011. Available from: <http:// www.ncbi.nlm.nih.gov/pubmed/21197597>. Accessed: Jan. 24, 2012. doi: 10.1007/s00709-010-0257-y.

MILLER, G. et al. Reactive oxygen species homeostasis and signaling during drought and salinity stresses. Plant, Cell and Environment, v.33, p.453-467, 2010.

MITTLER, R. Oxidative stress, antioxidants e stress tolerance. Trends in Plant Science, v.7, p.405-410, 2002. Available from: <http:// www.sciencedirect.com/science/article/pii/S1360138502023129>. Accessed: Jan. 24, 2012. doi: 10.1016/S1360-1385(02)02312-9.

MOLLER, I.M. et al. Oxidative modifications to cellular components in plants. Annual Review of Plant Biology, v.58, p.459-481, 2007. Available from: <http://www.ncbi.nlm.nih.gov/ pubmed/17288534>. Accessed: Jul. 12, 2011.

NAKANO, Y.; ASADA, K. Hydrogen peroxide is scavenged by ascorbate specific peroxidase in spinach chloroplast. Plant \& Cell Physiology, v.22, p.867-880, 1981. Available from: $<$ http://pcp.oxfordjournals.org/content/22/5/867.abstract $>$. Accessed: Sept. 25, 2011.

RIZHSKY, L. The response of to a combination of crought and heat stress. Plant Physiology, v.134, p.1683-1696, 2004. Available from: $<$ http://www.plantphysiol.org/content/134/4/1683>. Accessed: Sept. 08, 2011. doi: 10.1104/pp.103.033431.

SAIRAM, R.K. et al. Role of antioxidant systems in wheat genotypes tolerance to water stress. Biologia Plantarum, v.41, 
p.387-394, 1998. Available from: <http://link.springer.com/articl e/10.1023\%2FA\%3A1001898310321>. Accessed: Jul. 12, 2011. doi: 10.1023/A:1001898310321.

SILVA, FAS.; AZEVEDO, CAV. The Assistat Software Version 7.7 and its use in the analysis of experimental data. African Journal of Agricultural Research, vol.11, p.3733-3740, 2016. Available from: <http://www.assistat.com/indexp.html>. Accessed: May 30, 2017. doi: 10.5897/AJAR2016.11522.

SCANDALIOS, J.G. Oxidative stress: molecular perception and transduction of signals triggering antioxidant gene defenses. Brazilian Journal of Medical and Biological Research, v.38, p.995-1014, 2005. Available from: <http://www.ncbi.nlm.nih. gov/pubmed/16007271>. Accessed: May 05, 2012. doi: 10.1590/ S0100-879X2005000700003.

SHAO, H.B. et al. Changes of antioxidative enzymes and membrane peroxidation for soil water deficits among 10 wheat genotypes at seedling stage. Colloids and Surfaces B: Biointerfaces, v42, p.107-113, 2005.

SMIRNOFF, N. The role of active oxygen in the response of plants to water deficit and desiccation. New Phytologist, v.125, p.27-58, 1993. Available from: <http://onlinelibrary.wiley.com/ doi/10.1111/j.1469-8137.1993.tb03863.x/abstract>. Accessed: Sept. 08, 2011. doi: 10.1111/j.1469-8137.1993.tb03863.x.

TAYEBIMEIGOONI, A. et al. Leaf water status, proline content, lipid peroxidation and accumulation of hydrogen peroxide in salinized Chinese kale Brassicaalboglabra. Journal of Food, Agriculture \& Environment, v.10, p.371-374, 2012.

TRIANTAPHYLIDÈS, C. et al. Singlet oxygen is the major reactive oxygen species involved in photooxidative damage to plants. Plant Physiology, v.148, p.960-968, 2008.

WAHID, A.; CLOSE, T.J. Expression of dehydrins under heat stress and their relationship with water relations of sugarcane leaves. Biologia Plantarum, v.51, p.104-109, 2007. Available from: $<$ http://link.springer.com/article/10.1007\%2Fs10535-007-0021-0>. Accessed: Mar. 22, 2012. doi: 10.1007/s10535-007-0021-0.

WILLADINO, L. et al. Estresse salino em duas variedades de cana-de-açúcar: enzimas do sistema antioxidativo e fluorescência da clorofila. Revista Ciência Agronômica, v.42, p.417422, 2011. Available from: <http://www.redalyc.org/articulo. oa?id=195318915022>. Accessed: Nov. 15, 2012. 